\title{
In vitro assessment of potential bladder papillary neoplasm treatment with functionalized polyethyleneimine coated magnetic nanoparticles
}

\author{
Klemen Strojan, ${ }^{1}$ Jasna Lojk, ${ }^{1,2}$ Vladimir Boštjan Bregar, ${ }^{1}$ Mateja Erdani Kreft, ${ }^{2}$ \\ Jurij Svete, ${ }^{3}$ Peter Veranič ${ }^{2 * *}$ and Mojca Pavlin ${ }^{1,4^{*}}$ \\ ${ }^{1}$ Group for nano and biotechnological applications, University of Ljubljana, Faculty of Electrical Engineering, Tržaška cesta \\ 25, Ljubljana, Slovenia \\ ${ }^{2}$ Institute of Cell biology, University of Ljubljana, Faculty of Medicine, Vrazov trg 2, Ljubljana, Slovenia \\ ${ }^{3}$ Faculty of Chemistry and Chemical Technology, Večna Pot 113, Ljubljana, Slovenia \\ ${ }^{4}$ Institute of Biophysics, University of Ljubljana, Faculty of Medicine, Vrazov trg 2, Ljubljana, Slovenia \\ *Corresponding author: E-mail: mojca.pavlin@fe.uni-lj.si; peter.veranic@mf.uni-lj.si
}

Received: 01-09-2016

For Cutting Edge 2017

\begin{abstract}
Normal porcine urothelial cells have been shown to have a much lower rate of endocytosis than urothelial papillary neoplasm cells. This could be used as a mechanism for selective delivery of toxic compounds, such as polyethyleneimine coated nanoparticles (NPs). However, these NPs induce nonselective toxicity through direct membrane disruption. This toxicity can be reduced by functionalization of NPs with L-glutathione reduced or bovine serum albumin by reducing their surface charge. Functionalization was confirmed with Fourier Transform Infrared Spectroscopy, Dynamic Light Scattering and zeta potential measurements. Viability assays showed that bovine serum albumin coating reduced NPs cytotoxicity immediately after $3 \mathrm{~h}$ exposure and that such NPs were more toxic to urothelial papillary neoplasm cells compared to normal porcine urothelial cells at $50 \mu \mathrm{g} / \mathrm{ml} \mathrm{NPs} \mathrm{concentration.} \mathrm{However,} 24 \mathrm{~h}$ after exposure, bovine serum albumin functionalized NPs had similar effect on viability of both cell lines. NPs showed some selective toxicity towards urothelial papillary neoplasm cells compared to normal cells after $3 \mathrm{~h}$, however this was not confirmed after $24 \mathrm{~h}$.
\end{abstract}

Keywords: polyethyleneimine, urothelial cell models, magnetic nanoparticles, toxicity, urothelial papillary neoplasm

\section{Introduction}

Urothelial papillary neoplasms are a group of noninvasive urinary bladder cancers that have a high recurrence rate and can progress to an invasive form of bladder cancer. ${ }^{1,2}$ The treatment typically involves transurethral resection followed by intravesical therapy, where chemotherapeutic agents are administered directly into the bladder. ${ }^{3}$ Despite obvious advantages of local delivery, intravesical therapy has its limitations and is thus an important area for further development, ${ }^{4}$ in which nanoparticles (NPs) proved to be a promising strategy for improvement. $^{5}$
Several different types of NPs have already been designed for treatment of bladder cancer, mostly to deliver chemotherapeutic drugs and other therapeutic and imaging molecules. ${ }^{6-11}$ For targeted delivery to bladder cancer cells, different ligands have been used, such as lectins ${ }^{12,13}$ or transferrin. ${ }^{14}$ Also, magnetic targeting has been applied for delivery of magnetic NPs with encapsulated doxorubicin. ${ }^{15}$ In vivo studies demonstrated that complexation or encapsulation of cytotoxic agents into different NPs (liposomes, polymeric NPs) can improve the efficiency of intravesical therapy. ${ }^{6-11,16}$ Moreover, some NP formulations are already in preclinical and clinical studies. ${ }^{17}$

Furthermore, in a recent study we have shown enhanced uptake of anionic polyacrylic acid (PAA) coated 
cobalt ferrite NPs by urothelial papillary neoplasm cell model (RT4) compared to differentiated normal porcine urothelial cell model (NPU). Similar selective uptake was also shown for cationic chitosan coated poly- $\varepsilon$-caprolactone NPs by mouse bladder carcinoma cells compared to normal mouse urinary bladder cells. ${ }^{18}$ The highly localized intravesical treatment in combination with the significant difference in endocytic activity between normal and cancerous cells thus represents a unique opportunity for selective delivery of anti-cancer therapeutics, such as NPs.

In this paper we analyse potential applicability of polyethyleneimine (PEI) coated NPs for selective treatment of urothelial papillary cells. PEI is a cationic polymer with one of the highest cationic charge-density potentials, ${ }^{19}$ that is mostly used as a transfection agent. ${ }^{20,21}$ PEI has been already successfully applied as a delivery vehicle on bladder cancer models ${ }^{22,23}$ and researchers have also used PEI in a clinical study for the treatment of bladder cancer (NCT00595088). However, cationic properties of PEI are also responsible for its toxicity ${ }^{24-28}$ either through direct membrane damage (i.e. extracellular toxicity) or through damage to the endosomes, lysosomes and mitochondria (i.e. intracellular toxicity). ${ }^{25,26,29,30}$ So to achieve selective cytotoxicity of NPs for cancer cells compared to normal cells based on the selective NPs uptake into cancer cells, the extracellular toxicity of PEI NPs had to be reduced first.

The aim of the study was to design modified PEI NPs coated with the additional layer in order to obtain selective toxicity against cancer cells, and to test their effectiveness. We tested two coatings: L-glutathione reduced $(\mathrm{GSH})^{31}$ and bovine serum albumin (BSA) ${ }^{32,33}$ for which we hypothesized that would reduce extracellular toxicity (membrane toxicity) while retaining intracellular toxicity.

\section{Experimental}

\section{1. Nanoparticle Synthesis and Characterization}

PEI coated cobalt ferrite $\left(\mathrm{CoFe}_{2} \mathrm{O}_{4}\right)$ NPs were prepared as described previously. ${ }^{20,31,34}$ PEI NPs were additionally functionalized with L-glutathione reduced (GSH; Sigma-Aldrich, St. Luis, Missouri, USA) at 0.25 to 1 mass ratio (PEI_GSH NPs), or with bovine serum albumin (BSA; Sigma-Aldrich) at 0.5 to 1 mass ratio (PEI_BSA NPs) immediately prior to use. NPs were dialyzed against distilled water and sterilized by filtration. IR spectra of dry samples were recorded on a Bruker FTIR (Fourier Transform Infrared Spectroscopy) Alpha Platinum ATR spectrophotometer (Bruker, Billerica, Massachusetts, USA). Dynamic light scattering and zeta potential were measured using Malvern Zetasizer NanoZS (Malvern Industries, Malvern, UK).

\section{2. Cell Culturing}

Cells were maintained at $37{ }^{\circ} \mathrm{C}$ in a humidified $5 \%$ $\mathrm{CO}_{2}$ atmosphere. Human bladder papillary neoplasm (RT4) cells were grown in A-DMEM/F12 (Gibco, Gaithersburg, Maryland, USA), 5\% fetal bovine serum (FBS; Gibco), $4 \mathrm{mM}$ glutamax (Gibco), $100 \mathrm{U} / \mathrm{ml}$ penicillin, and $100 \mu \mathrm{g} / \mathrm{ml}$ streptomycin. Cultures of primary normal porcine urothelial cells (NPU) were established from porcine urinary bladder as described previously. ${ }^{35}$ For the establishment of the highly differentiated normal porcine urothelial (NPU) cell model, which represents a biomimetic model of a normal differentiated urothelium in vivo, cells were grown in UroM medium without FBS and with physiological $2.5 \mathrm{mM}$ calcium concentration for 3 weeks before experiments.

The experiments with NPU cells were approved by the Veterinary Administration of the Slovenian Ministry of Agriculture and Forestry in compliance with the Animal Health Protection Act and the Instructions for Granting Permits for Animal Experimentation for Scientific Purposes.

\section{3. Viability Testing}

Cell viability was determined with Trypan blue viability assay. Cells were incubated with PEI, PEI_GSH or PEI_BSA NPs $(50,100,150 \mu \mathrm{g} / \mathrm{ml})$ for $3 \mathrm{~h}$ in A-DMEM cell culture medium without FBS and washed to remove the NPs. Cells were trypsinized immediately after the $3 \mathrm{~h}$ incubation or after additional $24 \mathrm{~h}$ culturing in the complete medium (A-DMEM for RT4 cells and UroM for NPU cells) without NPs. Trypsinized cells were stained with Trypan Blue stain (Life Technologies, Eugene, Oregon, USA) and counted using Countess ${ }^{\mathrm{TM}}$ Automated Cell Counter (Invitrogen, Carlsbad, California, USA). The number of dead cells was subtracted from the total number of cells to obtain the number of viable cells. The percentage of viable cells (Viability) in a given sample was determined as the ratio between the number of viable cells in each sample $(N s)$ and the number of all cells in the control sample $\left(N_{0}\right)$ :

$$
\text { Viability }=100 \times N_{s} / N_{0} .
$$

\section{4. Transmission Electron Microscopy}

Transmission electron microscopy was performed as described in Bregar et al. ${ }^{34}$ following $3 \mathrm{~h}$ incubation with $50 \mu \mathrm{g} / \mathrm{ml}$ PEI and PEI_BSA NPs.

\section{5. Data Analysis}

Data analysis was performed in R software environment (version 3.2.2.). Results are shown as mean and standard error of the mean for three independent experiments. 


\section{Results and Discussion}

In our previous study, we showed that the uptake of PAA coated NPs is higher in the urothelial tumour cell models (RT4, T24) compared to NPU cells due to lower endocytic activity of healthy urothelial cells. Due to celltype dependent nature of such selective uptake, this principle could be applied also to other NP types, including PEI NPs. PEI NPs have so far been used for delivery of other toxic molecules, ${ }^{22,23}$ however PEI itself can also cause toxicity through membrane damage, ROS induction and lysosomal damage. ${ }^{36}$ We wanted to exploit PEI intrinsic toxicity as a mechanism to induce selective toxicity, but in order to limit PEI toxicity to NPU cells, PEI's ability to damage outer cell membranes (non-selective toxicity) had to be reduced. The aim of the study was to modify PEI NPs with the negatively charged GSH and BSA molecules to decrease PEI NPs highly positive surface charge and thus to obtain selective toxicity. GSH was chosen for its antioxidant properties and excess of negative charge, in order to reduce the zeta potential of the modified (PEI_GSH NPs). This strategy proved to be efficient for reducing cytotoxicity of PEI_NPs towards CHO cells. ${ }^{31}$ BSA was used as a protein pre-coating, a strategy described in Mirshafie et $_{\text {al. }}{ }^{32}$

The successful modifications were confirmed with physicochemical characterization of NPs through the differences in FTIR spectra (Figure 1), changes in DLS (Figure 2a) and zeta potential measurements (Figure 2B). DLS measurements showed that functionalization with GSH reduced the hydrodynamic diameter of PEI NPs (122 $\pm 19 \mathrm{~nm}$ ) to $93 \pm 32 \mathrm{~nm}$, indicating additional stabilization of NPs by GSH in distilled water (Figure 2a). This effects was most probably due to steric repulsion of GSH molecules on PEI NP surface, which impeded the formation of NP aggregates. ${ }^{37}$ On the other hand, BSA coating increased the hydrodynamic diameter to $179 \pm 6 \mathrm{~nm}$. Upon additional functionalization, the highly positive zeta potential of PEI NPs $(56 \pm 1 \mathrm{mV})$ was reduced to $44 \pm 5 \mathrm{mV}$ and $50 \pm$ $4 \mathrm{mV}$ for GSH and BSA, respectively (Figure 2B). This was due to interaction of anionic GSH or BSA molecules with cationic PEI NPs, which neutralized some of the functional groups on the surface of PEI NPs.

We postulated that reduction of the highly positive charge of PEI NPs would decrease their binding to the plasma membrane and thus reduce the membrane damage and increasing their selective toxicity. Moreover, we assumed that the exposure to acidic $\mathrm{pH}$ and proteolytic enzymes in the lysosomes would damage the GSH and BSA layers, thus exposing again the highly cationic surface of PEI NPs and enabling intracellular cytotoxic action of PEI. It is important to note that if the incubation of NPs would be performed in a standard culture medium with serum, this could modify internalization and the cytotoxicity, since protein corona importantly determines biological response of the cells to NPs. ${ }^{38}$ a)

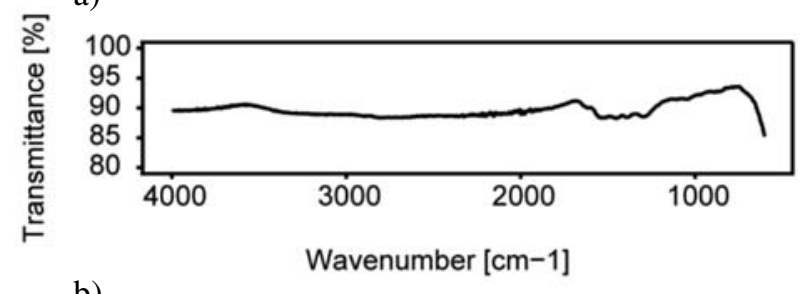

b)

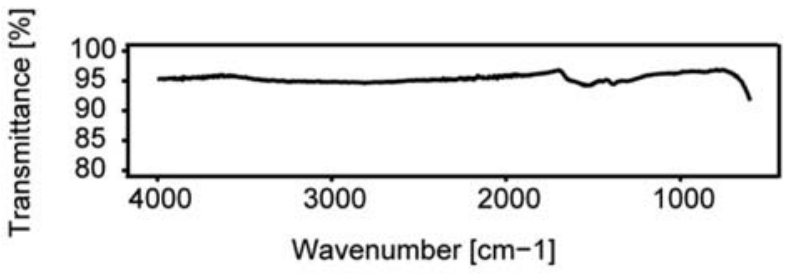

c)

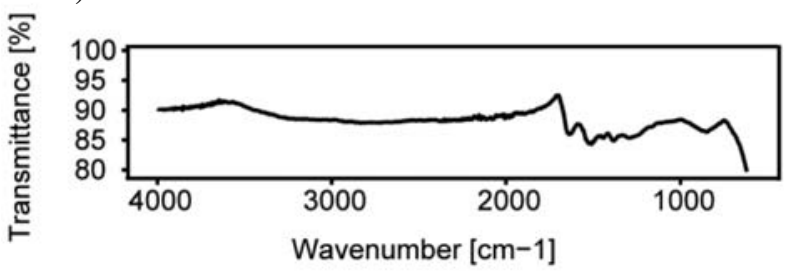

Figure 1: FTIR spectra of PEI (a), PEI_GSH (b) and PEI_BSA (c) NPs.

a)
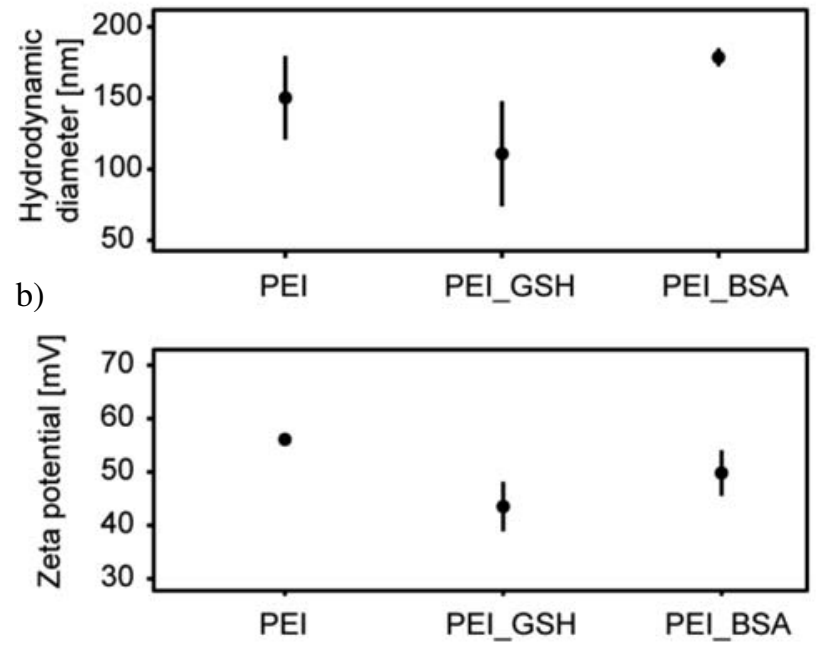

Figure 2: Physical characterization of NPs. Hydrodynamic diameter of PEI, PEI_GSH and PEI_BSA NPs dispersed in water (a). Zeta potential of PEI, PEI_GSH and PEI_BSA NPs dispersed in water (b). Means with standard errors of the mean from three independent experiments are shown.

To simulate potential intravesical therapy, normal (NPU) and papillary neoplasm (RT4) urothelial cell models were exposed to increasing concentrations of the three types of NPs for $3 \mathrm{~h}$ and viability was determined with Trypan blue viability assay (Figure 3 ). Experiments were performed in the media without FBS, as this was 
more relevant for potential in vivo application. Immediately after the incubation, a significant proportion of dead cells was observed in all treated samples, among which PEI NPs predictably induced the highest toxicity. BSA coating (PEI_BSA NPs) showed the highest reduction of PEI NPs toxicity, resulting in increased NPU cell viability at concentrations 50 and $100 \mu \mathrm{g} / \mathrm{ml}$ (Figure 3A). The hig-

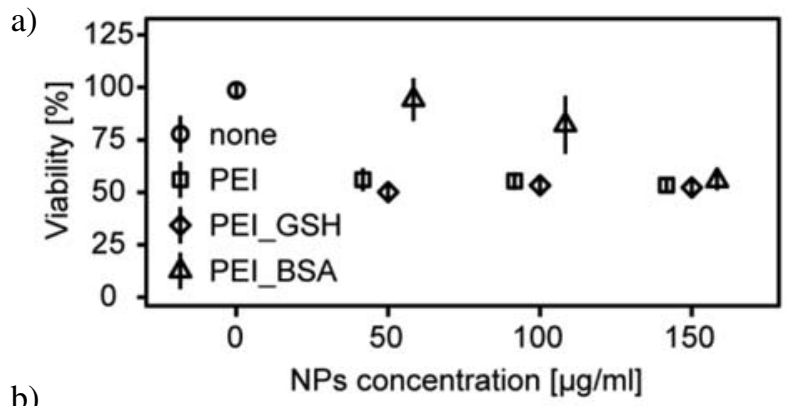

b)

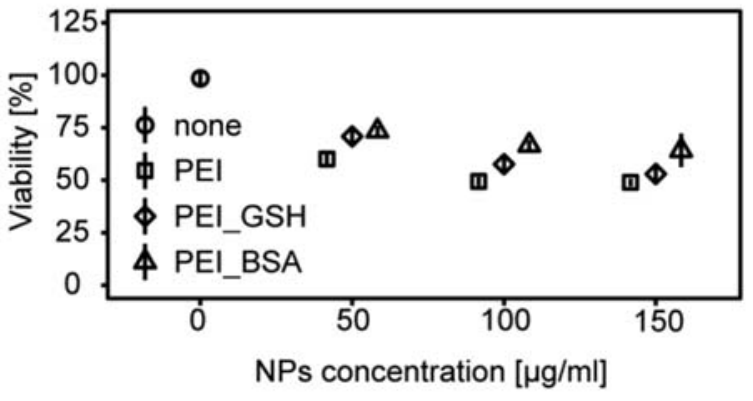

Figure 3: Viability of NPU (a) and RT4 (b) cells immediately after $3 \mathrm{~h}$ exposure to increasing concentrations of PEI, PEI_BSA and PEI_GSH NPs. Viability was determined by Trypan Blue viability assay. Means with standard errors of the mean from three independent experiments are shown. hest selective toxicity was obtained with $50 \mu \mathrm{g} / \mathrm{ml}$ PEI_BSA NPs, where the obtained viability was $90 \%$ and $75 \%$ for NPU and RT4 cells, respectively. On the other hand, PEI and PEI_GSH NPs induced no selective toxicity to RT4 compared to NPU cells (Figure 3). Interestingly, the overall cytotoxicity of NPs was greater in NPU cells than in RT4 cells, which is most probably due to a higher number of cell layers in RT4 cell model, but could also be due to the different molecular composition of cell membrane in RT4 and NPU cells. ${ }^{39}$

Interestingly, the increasing NP concentration had only a small effect on cell viability. This can be explained by short exposure time, which limited the sedimentation and internalization of NPs. Moreover, cells in these cell models grow in confluent layers, thus limiting the exposure to NPs only to the uppermost layer. All used NP concentrations were enough to damage the first layer and the remaining cell debris protected the lower laying cells. This was confirmed with TEM analysis, where following $3 \mathrm{~h}$ incubation, NPs were observed in contact only with the uppermost cell layer of RT4 in membrane structures which could represent macropinocytotic uptake (Figure 4) and possibly lead to internalization of NPs. No NPs were observed associated with NPU cells (Figure 4).

To determine, if these NPs can cause delayed selective toxicity, cell models were cultured for additional $24 \mathrm{~h}$ after the initial $3 \mathrm{~h} \mathrm{NP}$ exposure (Figure 5). PEI and PEI_BSA NPs caused additional cytotoxicity to RT4 cells after $24 \mathrm{~h}$ compared to cytotoxicity determined immediately after $3 \mathrm{~h}$ exposure, partially due to intracellular toxicity, and also partially due to delayed effect of the $3 \mathrm{~h} \mathrm{ex}-$ posure to NPs. The later effect was confirmed on NPU

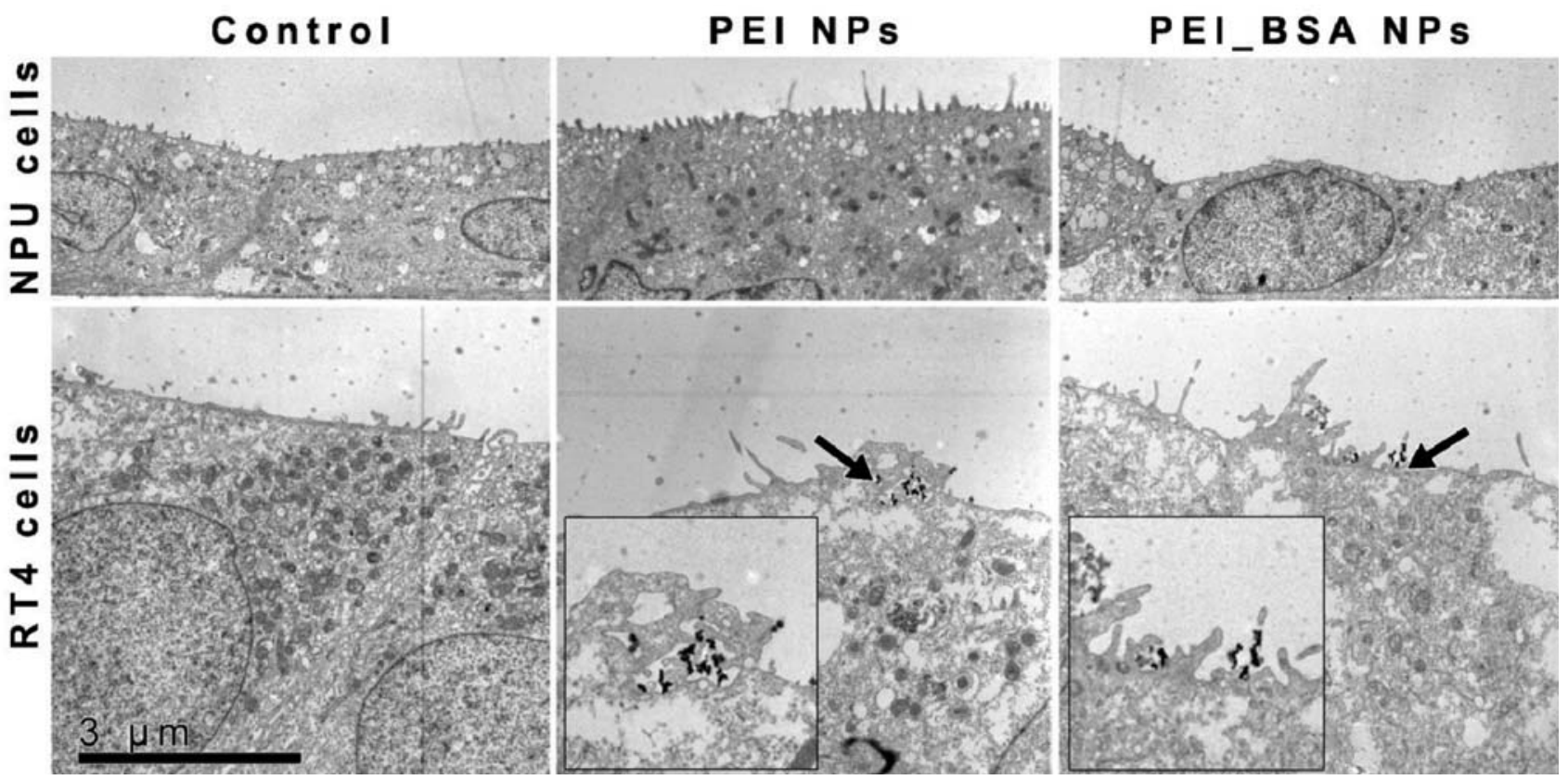

Figure 4: TEM micrographs of NPU and RT4 cells without NPs (control), with $50 \mu \mathrm{g} / \mathrm{ml}$ PEI NPs or $50 \mu \mathrm{g} / \mathrm{ml}$ PEI_BSA NPs after $3 \mathrm{~h}$ incubation. Arrows denote NPs. 
a)

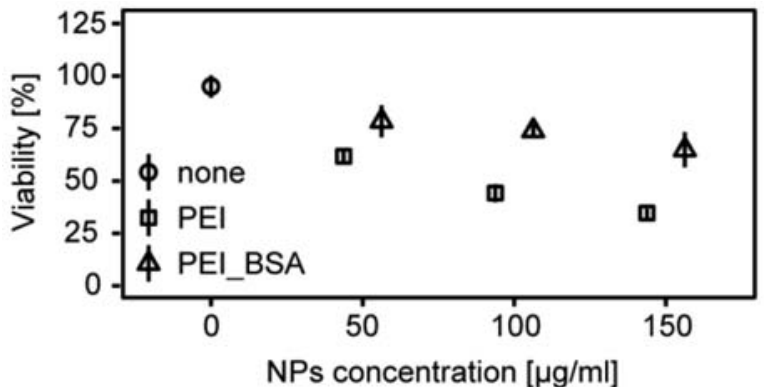

b)

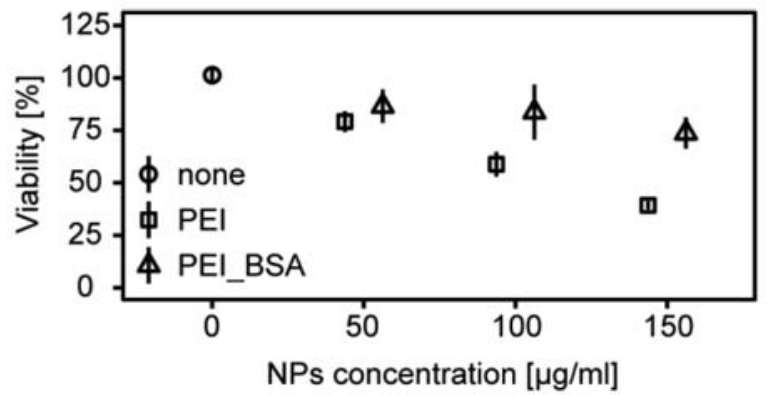

Figure 5: Viability of NPU (a) and RT4 (b) cells 24h after the $3 \mathrm{~h}$ exposure to increasing concentrations of PEI and PEI_BSA NPs. Viability was determined 24h after the removal of NPs, by Trypan blue viability assay. Means with standard errors of the mean from three independent experiments are shown.

cells, since s reduced viability was observed for both PEI and PEI_BSA NPs. For both cell lines, this reduction in viability could be caused by NPs that remained on the surface of cell models after the washing step. Again, PEI_BSA NPs proved to be less toxic to NPU and RT4 cells compared to PEI NPs at equal concentrations. Also, only a negligible number of dead cells were observed (results not shown), indicating that the damaged cells were washed away, and leaving only healthy cells to regenerate the urothelium. Thus, analysis after $24 \mathrm{~h}$ showed that developed NP formulations exhibit no selective toxicity for cancer RT4 cells.

Unfortunately, despite the promising results on the reduction of PEI NP toxicity, the additional BSA coating did not induce selective toxicity towards cancer cells. This is partially caused by the still high extracellular toxicity of modified NPs at the concentrations used, but could also be due to the short incubation time, which significantly limited the interactions between NPs and cell membranes and thus also the amount of internalized NPs in RT4 cells. Additional strategies to more effectively reduce the extracellular toxicity of PEI NPs should thus be explored.

\section{Conclusions}

PEI NPs were successfully coated with GSH or BSA and the functionalization was confirmed with FTIR, DLS and zeta potential measurements. Reduced extracellular toxicity of PEI NPs with additional functionalization proved to be a promising method for achieving selective toxicity to urothelial cells after $3 \mathrm{~h}$ of exposure, as indicated by the reduced cytotoxicity of BSA modified PEI NPs towards NPU cells compared to RT4 cells. However, viability experiments performed $24 \mathrm{~h}$ after the initial exposure to NPs indicated that further optimisation is needed in order to decrease nonspecific membrane toxicity of NPs and thus obtain therapeutic window with specific cytotoxicity to RT4 cancer cells.

\section{Acknowledgements}

We express gratitude to Urša Tomažin, Sanja Čabraja, Linda Štrus, Nada Pavlica Dubarič, and Sabina Železnik for their technical assistance. The study was supported by the Slovenian Research Agency (Grants No. J7-7424, J3-6794, J2-6758, P1-0055, J3-7494, P3-0108, and Young Researchers Program).

\section{References}

1. J. I. Epstein, Int. J. Surg. Pathol. 2010, 18, 106S-111S. https://doi.org/10.1177/1066896910370471

2. J. K. McKenney, M. B. Amin, R. H. Young, Mod. Pathol. 2003, 16, 623-629.

https://doi.org/10.1097/01.MP.0000073973.74228.1E

3. S. Holmang, H. Hedelin, C. Anderstrom, E. Holmberg, C. Busch, S. L. Johansson, J. Urol. 1999, 162, 702-707. https://doi.org/10.1097/00005392-199909010-00019

4. J. Nirmal, Y.-C. Chuang, P. Tyagi, M. B. Chancellor, Urol. Sci. 2012, 23, 70-77. https://doi.org/10.1016/j.urols.2012.07.005

5. L. Neutsch, M. Wambacher, E.-M. Wirth, S. Spijker, H. Kählig, M. Wirth, F. Gabor, Int. J. Pharm. 2013, 450, 163-176. https://doi.org/10.1016/j.ijpharm.2013.04.058

6. G. Chen, Y. He, X. Wu, Y. Zhang, C. Luo, P. Jing, Braz. J. Med. Biol. Res. 2012, 45, 771-776. https://doi.org/10.1590/S0100-879X2012007500111

7. N. Erdoğar, A. B. Iskit, H. Eroğlu, M. F. Sargon, N. A. Mungan, E. Bilensoy, J. Nanosci. Nanotechnol. 2015, 15, 10156-10164. https://doi.org/10.1166/jnn.2015.11690

8. M. R. Kang, G. Yang, R. F. Place, K. Charisse, H. Epstein-Barash, M. Manoharan, L.-C. Li, Cancer Res. 2012, 72, 50695079. https://doi.org/10.1158/0008-5472.CAN-12-1871

9. J.-H. Kim, Y.-S. Kim, K. Park, S. Lee, H. Y. Nam, K. H. Min, H. G. Jo, J. H. Park, K. Choi, S. Y. Jeong, R.-W. Park, I.-S. Kim, K. Kim, I. C. Kwon, J. Control. Release Off. J. Control. Release Soc. 2008, 127, 41-49. https://doi.org/10.1016/j.jconrel.2007.12.014

10. D. T. Martin, C. J. Hoimes, H. Z. Kaimakliotis, C. J. Cheng, K. Zhang, J. Liu, M. A. Wheeler, W. K. Kelly, G. N. Tew, W. M. Saltzman, R. M. Weiss, Nanomedicine Nanotechnol. Biol. Med. 2013, 9, 1124-1134.

https://doi.org/10.1016/j.nano.2013.05.017 
11. C. Mugabe, Y. Matsui, A. I. So, M. E. Gleave, J. H. E. Baker, A. I. Minchinton, I. Manisali, R. Liggins, D. E. Brooks, H. M. Burt, Clin. Cancer Res. Off. J. Am. Assoc. Cancer Res. 2011, 17, 2788-2798. https://doi.org/10.1158/1078-0432.CCR-10-2981

12. L. Neutsch, E.-M. Wirth, S. Spijker, C. Pichl, H. Kählig, F. Gabor, M. Wirth, J. Control. Release Off. J. Control. Release Soc. 2013, 169, 62-72.

https://doi.org/10.1016/j.jconrel.2013.04.004

13. L. Neutsch, M. Wambacher, E.-M. Wirth, S. Spijker, H. Kählig, M. Wirth, F. Gabor, Int. J. Pharm. 2013, 450, 163-176. https://doi.org/10.1016/j.ijpharm.2013.04.058

14. A. S. L. Derycke, A. Kamuhabwa, A. Gijsens, T. Roskams, D. De Vos, A. Kasran, J. Huwyler, L. Missiaen, P. A. M. de Witte, J. Natl. Cancer Inst. 2004, 96, 1620-1630. https://doi.org/10.1093/jnci/djh314

15. T. Leakakos, C. Ji, G. Lawson, C. Peterson, S. Goodwin, Cancer Chemother. Pharmacol. 2003, 51, 445-450.

16. Z. Lu, T.-K. Yeh, J. Wang, L. Chen, G. Lyness, Y. Xin, M. G. Wientjes, V. Bergdall, G. Couto, F. Alvarez-Berger, C. E. Kosarek, J. L.-S. Au, J. Urol. 2011, 185, 1478-1483. https://doi.org/10.1016/j.juro.2010.11.091

17. T. Sun, Y. S. Zhang, B. Pang, D. C. Hyun, M. Yang, Y. Xia, Angew. Chem. Int. Ed. 2014, 53, 12320-12364.

18. E. Bilensoy, C. Sarisozen, G. Esendağll, A. L. Doğan, Y. Aktaş, M. Şen, N. A. Mungan, Int. J. Pharm. 2009, 371, 170-176. https://doi.org/10.1016/j.ijpharm.2008.12.015

19. O. Boussif, F. Lezoualc'h, M. Antoniet. Zanta, M. D. Mergny, D. Scherman, B. Demeneix, J.-P. Behr, Proc. Natl. Acad. Sci. 1995, 92, 7297-7301. https://doi.org/10.1073/pnas.92.16.7297

20. S. Prijic, L. Prosen, M. Cemazar, J. Scancar, R. Romih, J. Lavrencak, V. B. Bregar, A. Coer, M. Krzan, A. Znidarsic, G. Sersa, Biomaterials 2012, 33, 4379-4391. https://doi.org/10.1016/j.biomaterials.2012.02.061

21. F. Scherer, M. Anton, U. Schillinger, J. Henkel, C. Bergemann, A. Kruger, B. Gansbacher, C. Plank, Gene Ther. 2002 , 9, 102-109. https://doi.org/10.1038/sj.gt.3301624

22. C. Mugabe, B. A. Hadaschik, R. K. Kainthan, D. E. Brooks, A. I. So, M. E. Gleave, H. M. Burt, BJU Int. 2009, 103, 978986. https://doi.org/10.1111/j.1464-410X.2008.08132.x

23. P. Sweeney, T. Karashima, H. Ishikura, S. Wiehle, M. Yamashita, W. F. Benedict, R. J. Cristiano, C. P. N. Dinney, Cancer
Res. 2003, 63, 4017-4020.

24. T.-L. Hwang, I. A. Aljuffali, C.-F. Lin, Y.-T. Chang, J.-Y. Fang, Int. J. Nanomedicine 2015, 10, 371-385.

25. S. Moghimi, P. Symonds, J. Murray, A. Hunter, G. Debska, A. Szewczyk, Mol. Ther. 2005, 11, 990-995. https://doi.org/10.1016/j.ymthe.2005.02.010

26. C. Hoskins, A. Cuschieri, L. Wang, J Nanobiotechnol 2012 , $10,15$.

27. D. Fischer, Y. Li, B. Ahlemeyer, J. Krieglstein, T. Kissel, Biomaterials 2003, 24, 1121-1131. https://doi.org/10.1016/S0142-9612(02)00445-3

28. E. Fröhlich, Int. J. Nanomedicine 2012, 5577. https://doi.org/10.2147/IJN.S36111

29. L. Parhamifar, A. K. Larsen, A. C. Hunter, T. L. Andresen, S. M. Moghimi, Soft Matter 2010, 6, 4001. https://doi.org/10.1039/c000190b

30. R. V. Benjaminsen, M. A. Mattebjerg, J. R. Henriksen, S. M. Moghimi, T. L. Andresen, Mol. Ther. 2012, 21, 149-157. https://doi.org/10.1038/mt.2012.185

31. K. Strojan, J. Lojk, V. B. Bregar, P. Veranič, M. Pavlin, Toxicol. In Vitro 2017, DOI 10.1016/j.tiv.2017.02.007.

32. V. Mirshafiee, R. Kim, S. Park, M. Mahmoudi, M. L. Kraft, Biomaterials 2016, 75, 295-304. https://doi.org/10.1016/j.biomaterials.2015.10.019

33. A. O. Elzoghby, W. M. Samy, N. A. Elgindy, J. Controlled Release 2012, 157, 168-182. https://doi.org/10.1016/j.jconrel.2011.07.031

34. V. B. Bregar, J. Lojk, V. Šuštar, P. Veranič, M. Pavlin, Int. J. Nanomedicine 2013, 8, 919-931.

35. T. Višnjar, P. Kocbek, M. E. Kreft, Histochem. Cell Biol. 2012, 137, 177-186. https://doi.org/10.1007/s00418-011-0893-0

36. H. Lv, S. Zhang, B. Wang, S. Cui, J. Yan, J. Controlled Release 2006, 114, 100-109. https://doi.org/10.1016/j.jconrel.2006.04.014

37. H. Li, Z. Cui, C. Han, Sens. Actuators B Chem. 2009, 143, 87-92. https://doi.org/10.1016/j.snb.2009.09.013

38. A. Lesniak, F. Fenaroli, M. P. Monopoli, C. Åberg, K. A. Dawson, A. Salvati, ACS Nano 2012, 6, 5845-5857. https://doi.org/10.1021/nn300223w

39. N. Resnik, U. Repnik, M. E. Kreft, K. Sepčić, P. Maček, B. Turk, P. Veranič, PLOS ONE 2015, 10, e0137878. https://doi.org/10.1371/journal.pone.0137878

\section{Povzetek}

Normalne prašičje urotelijske celice imajo nižjo stopnjo endocitoze kot urotelijske celice papilarne neoplazme. To lahko izkoristimo kot mehanizem za selektivno dostavo nanodelcev oplaščenih s polietileniminom. Nanodelci pa lahko delujejo toksično tudi preko interakcije s celično membrano. Tej toksičnosti se lahko izognemo z dodatno plastjo nasprotno nabitih molekul na površini nanodelcev. V našem primeru smo to želeli doseči z dodatno plastjo glutationa oziroma govejega serumskega albumina. Test viabilnosti je pokazal, da dodatna plast govejega serumskega albumina uspešno zmanjša neselektivno citotoksičnost nanodelcev takoj po $3 \mathrm{~h}$ izpostavitvi. Taisti nanodelci so izkazali višjo citotoksičnost na urotelijskih celicah papilarne neoplazme v primerjavi z normalnimi prašičjimi urotelijskimi celicami pri koncentraciji $50 \mu \mathrm{g} / \mathrm{ml}$. 24 h po izpostavitvi je učinek nanodelcev enak na obeh celičnih linijah. 